\title{
Stress Urinary Incontinence After Holmium Laser Enucleation of Prostate: Incidence and Risk Factors
}

\author{
haixia ye ( $\nabla$ dr.haixia.ye@gmail.com ) \\ Hôpital Édouard-Herriot \\ ricardo codas \\ Hôpital Édouard-Herriot \\ theresa daily \\ Hôpital Édouard-Herriot \\ lionel badet \\ Hôpital Édouard-Herriot \\ marc colombel \\ Hôpital Édouard-Herriot \\ hakim fassi-fehri \\ Hôpital Édouard-Herriot
}

\section{Research Article}

Keywords: laser, prostatic hyperplasia, urinary incontinence, holmium

Posted Date: January 18th, 2021

DOl: https://doi.org/10.21203/rs.3.rs-143301/v1

License: (a) This work is licensed under a Creative Commons Attribution 4.0 International License. Read Full License 


\section{Abstract}

\section{Objectives:}

To evaluate the incidence and the risk factors of stress urinary incontinence (SUI) during the first year after HoLEP.

\section{Patients and Methods:}

This study presents a monocentric and retrospective study including 155 patients who underwent HoLEP for benign prostatic hyperplasia. The surgeries were performed by 2 expert surgeons. The continence was evaluated at 1, 3, 6 and 12 months. The predictive factors of SUI were analysed by logistic regression.

\section{Results:}

The SUI rate at 1, 3 and 6 months was $11.3 \%, 10.7 \%$ and $4.1 \%$ respectively. SUI remained present in 4 patients (2.6\%) at 12 months. The mean ICIQ-SF scores in patients with SUI were $10.3 \pm 6.09$ and $8 \pm 4.24$ at 1 and 12 months respectively $(\mathrm{p}<0.05)$. BMI>30 $(\mathrm{OR}, 4.69 ; 95 \% \mathrm{Cl}, 1.51-14.52 ; \mathrm{p}=0.007)$ and patients over 70 years old $(\mathrm{OR}, 16.23 ; 95 \% \mathrm{Cl}, 1.96-134.09 ; \mathrm{p}=0.010)$ were identified as independent risk factors for SUI at 1 and 3 months respectively.

\section{Conclusion:}

SUl after HoLEP is transitory in most cases. It is favoured by a high BMI and an age over 70 . These criteria should be considered before choosing the operative technique and preventive measures must be taken in high-risk patients.

\section{Introduction}

Transurethral resection of the prostate (TURP) and open prostatectomy (OP) still remains the 'gold standard' surgical treatment for symptomatic benign prostatic hyperplasia $(\mathrm{BPH})$ resistant to medical treatment $[1,2]$.

Currently, Holmium laser enucleation of the prostate (HoLEP) has become an important alternative treatment modality to TURP and OP [3]. This endoscopic approach enables a complete excision of the adenoma whatever its volume. Comparatively to TURP and OP, HoLEP improves patient recovery by reducing blood loss, urinary catheterisation duration and hospitalization length. Moreover, functional results are equivalent to conventional techniques $[3,4]$.

Post-operative stress urinary incontinence (SUI) has been reported after HoLEP, with a negative influence on the patient's quality of life (QoL) $[5,6]$. This complication can concern up to $16 \%$ of patients 3 months after surgery, but is most often transient [7].

From a technical point of view, the difference between TURP/OP and HoLEP is the direction of adenoma dissection. In a HoLEP procedure, dissection is carried out retrogradely through the urethral sphincter (transsphincter endoscopic enucleation). This method could induce sphincter lesion if the apical adenoma is 
improperly dissected [8]. Surgeons during their learning phase are especially prone to this mistake [5]. However, SUI has also been reported after HoLEP performed by experienced surgeons $[9,10]$.

Several studies have identified peri operative urinary incontinence risk factors based on patient-reported data $[10,11]$, but only a few have used validated urinary incontinence questionnaires in order to distinguish the different types of incontinence and their incidence [12,13].

The aim of this study was to evaluate the incidence of de novo stress urinary incontinence after HoLEP and to identify predicting risk factors.

\section{Materials And Methods}

A retrospective monocentric study was performed using observational data from all patients undergoing HoLEP for symptomatic BPH with no satisfactory response to medication therapy between May 2018 and December 2019. The procedure was carried out in patients with moderate to severe lower urinary tract symptoms and/or severe urinary retention and/ or other complications related to BPH. Patients with bladder or prostate cancer (except those on active surveillance), urethral stenosis, self catheterism, chronic renal failure or cognitive disorders, were excluded from the study. HoLEP procedures were conducted by 2 experts surgeons with an experience of more than 200 HoLEPs each one.

\section{Surgical technique}

Enucleation was performed according to the three-lobe technique described by Gilling [14] with early apical dissection using the white line technique to differentiate between apical adenoma and urethral sphincter. For enucleation, a reusable $1000 \mu$ laser fiber was inserted through a $24.5 \mathrm{Fr}$ endoscope and the holmium generator was set to $100 \mathrm{~W}(2 \mathrm{~J}, 50 \mathrm{~Hz})$. The Morscope Wolf Piranha ${ }^{\mathrm{T}}$ was used for morcellation of the adenoma.

Enucleation of the lobes was performed using the retrograde approach. The first step was to prepare the bladder neck by making a $\mathrm{T}$ incision at 5 and 7 o'clock to avoid ureteral meatus injury during midlobe enucleation. The second step involved detaching each lateral lobe at the apex of the adenoma, starting with a superficial incision of the mucosa at low power ( $20 \mathrm{~W}$ ) (white line technique). The posterior incision opposite the veru (hockey stick-shaped) joined a second anterior incision to form an inverted Y. Once released at the apex, the lateral lobe was gradually pushed back into the plane of the capsule by the ballistic action of the laser beam at $100 \mathrm{~W}$. In order to limit potential effects of leverage on the sphincter, no mechanical push was applied to the endoscope. (video: Duarte RC, Daily T, Fassi-Fehri H. HoLEP dangers: How to avoid them. Eur Urol Suppl. 1 mars 2018;17(2):e1981.)

\section{Additional measures}

Pelvic floor muscle training (PFMT) was systematically prescribed if SUI was reported by patients at the first follow-up.

\section{Assessment of voiding status and continence}


Patients' pre-operative evaluation included IPSS, Qol-IPSS and ICIQ-SF questionnaires as well as a clinical and rectal examination, a flow measurement including post-void residual volume (PVR), an assessment of prostatic volume by trans-rectal ultrasound and a PSA test.

The post-operative evaluation was systematically carried out at 1, 3, 6 and 12 months. At each point of follow up, a flow measurement with PVR as well as IPSS, Qol-IPSS and ICIQ-SF questionnaires were collected. The number of daily urinary pads was also noted at each visit. The PSA test was performed at 3 and 12 months.

\section{General data}

Demographic data, perioperative data were collected in a standardized and retrospective manner from the computerized medical record of each patient.

\section{Statistical analysis}

Statistical analyses were performed with SPSS Statistics (IBM SPSS Statistics Version 20). To compare preand post-operative continence status, a nonparametric t test was used. The predictive factors for the occurrence of post-operative SUI were analysed by logistic regression. A P value of $<0.05$ was considered as statistically significant.

\section{Ethics}

This study was approved by the ethics committee of the Hospices Civils de Lyon and registered with the CNIL (Commission Nationale de l'Informatique et des Libertés) under number 18-127.

\section{Results}

One hundred and seventy-five HoLEPs were carried out consecutively in our institution, of which 155 were assessed. (Figure 1) The demographic and perioperative data are set out in Table 1. Complete functional results at 1, 3, 6 and 12 months are reported in Table 1. The nature and severity of urinary leakage is detailed in Table 2. The rates of SUI de novo at 1, 3 and 6 months post-surgery were $11.3 \%, 10.7 \%$ and $4.1 \%$ respectively. Despite beginning bladder and sphincter rehabilitation in the first postoperative month in all patients with urinary leakage, SUI persisted in 4 patients (2.6\%) at 12 months. However, only 2 patients (1.3\%) wore one pad per day at 12 months. The mean ICIQ-SF scores for patients with SUI were $11.69 \pm 5.28$, $8.70 \pm 4.24,1.81 \pm 3.53$ and $8 \pm 4.24$ at $1,3,6$ and 12 months, respectively (Table 2 ). In univariate and multivariate analysis, Body Mass Index $(\mathrm{BMI})>30(\mathrm{OR}, 4.69 ; 95 \% \mathrm{Cl}, 1.51-14.52 ; \mathrm{p}=0.007)$ was an independent risk factor for the occurrence of post-operative SUI at 1 month, whereas age > 70 years (OR, 16.23; 95\% Cl, 1.96-134.09; $\mathrm{p}=0.010$ ) was an independent risk factor for occurrence at 3 months (Table 3 ). At the time of the study, none of the patients presenting SUI required an implantable device.

\section{Discussion}

Transient stress urinary incontinence is a complication commonly reported after HoLEP. Its occurrence varies in the literature from 3.3 to $26 \%$ at 3 months (Table 4). Fortunately, most cases recover within the first year [7]. However, its assessment in several studies is based only on patient reported data (Table 4), and one possible 
explanation for the variation of reported SUI rates is the lack of a standard evaluation. Without the use of a validated questionnaire, incidence and prevalence of postoperative urinary incontinence could be underestimated, and precise determination of the type of incontinence is difficult [15]. The ICIQ-SF is a validated questionnaire in male urinary incontinence that distinguishes different types of urinary incontinence and estimates their severity [16]. The present study showed $11.4 \%$ and $10.5 \%$ de novo SUI at 1 month and 3 months respectively. The use of the same questionnaire at each follow up point confirmed the transient nature of SUI. Indeed, only 4 patients $(2.6 \%)$ reported a persistent mild urinary leakage at one year despite PFMT.

Two main independent demographic risk factors for the occurrence of SUI during the first 3 postoperative months were identified: age greater than 70 years $(p<0.02)$ and a BMI greater than $30(p<0.007)$. These results confirm those of Nam et al [7] who reported, in a retrospective series of 391 patients, a significantly higher rate of transient SUI in patients over 65 years old. In another retrospective and multicentric series of 2346 patients, increasing age and elevated BMI were also significantly associated with urinary incontinence [17]. Other demographic risk factors such as a history of diabetes mellitus and a pre-operative prostate volume greater than $81 \mathrm{~g}$ have also been reported [17] but were not found in our study. Intrinsic sphincter insufficiency in elderly, overweight and diabetic patients could favour the occurrence of transient SUI after endoscopic enucleation [18].

In this study, we did not identify any intraoperative factor that could induce transient SUI. However, during HoLEP, some factors could cause an occlusion defect of the urethra-sphincter complex which leads to transient SUl: widening of the bladder neck, tearing of muscle fibres due to excessive use of mechanical thrust, heat damage to muscle fibres due to excessive use of laser energy at the apex of the adenoma, incomplete occlusion due to circumferential tearing of the proximal sphincter's mucosa (seal effect). Elmansy et al showed that a decrease in PSA level greater than $84 \%$, reflecting the amount of removed prostate tissue, was associated with a higher risk of stress urinary incontinence [19]. Similarly, enucleation weight have been considered as an independent intraoperative predictive factor of urinary incontinence at 3 and 6 months[17]. In the same way, technical difficulty like poor visibility of the operating field due to excessive bleeding was linked to a higher risk of inappropriate endoscopic manipulations and thus urethral sphincter injury $[7,19,20]$. Several authors have also suggested that reducing the energy delivered during enucleation, in particular when near the urethral sphincter, could minimize the risk of thermal damage without increasing operating time[12]. Unfortunately, no consensus for the optimal setting has yet been reached.

Several HoLEP techniques have been reported since the first procedure described by Gilling [14] : 2-lobes technique[21], En-Bloc technique[22], white line technique[23,24], anteroposterior dissection HoLEP [25], TopDown HoLEP [26] . In a non-randomized retrospective monocentric study, Endo and al [25] reported a decrease of incontinence rate $(2.7 \%$ vs $25.2 \%)$ in favour of anteroposterior dissection HoLEP versus Gilling's method. However, these results have not yet been confirmed. As described earlier, our technique is a mix of the white line and the 3-lobe techniques. Our modifications based on early apex dissection avoid stretching the urethral sphincter by first separating the adenoma from the sphincter area. Lateral lobe enucleation was carried out through the adenoma apex until reaching the capsule. Small apical adenomatous remnants were left in place as sphincter protective flaps. With this method, only 2 patients $(1.3 \%)$ reported a persistent mild stress urinary 
incontinence requiring one pad per day at one year. However, in the absence of comparative studies, it is impossible to identify one technique that would preserve continence more safely.

In our study, HoLEP was carried out by 2 operators which had conducted at least 200 HoLEP procedures. it is well known that the learning curve affects the incidence of SUI after HoLEP [7,11]. Fifty procedures at least are necessary to master the technique [26]. In this phase, the unassisted beginner surgeon is exposed to an increased risk of SUI by sphincter injury due to an inappropriate apex dissection $[9,11,13]$ as well as an excessive operating time [27]. For these reasons, increased initial case density [11] and structured mentorship programs (video viewing, simulator training and active proctoring) are needed to improve the safety of HoLEP procedures [28]. Moreover, avoiding potentially complicated cases (prostate volumes greater than $80 \mathrm{~g}$, anticoagulated patients, patients with prostate cancer, prior prostatic radiotherapy) during the learning phase has been recommended[26].

The current study has several limitations, as a non-controlled study with a retrospective design and a small number of patients. In addition, there were no objective measurements, such as a pad test or a voiding diary. Finally, urodynamic tests other than uroflowmetry were not routinely performed. However, the use of the same surgical technique by two experienced operators in the same hospital and the systematic evaluation of postoperative urinary incontinence by a standardized and validated questionnaire, made it possible to reduce biases due to patients interview, learning curve and different practices.

\section{Conclusion}

In this study, we reported a low SUI rate one year after HoLEP. Transient SUI was more frequent in elderly and overweight patients. These results should be taken into consideration when informing patients about postoperative complications. We suggest that careful patient selection and appropriate preventive and therapeutic care (weight loss, PFMT) could be helpful in decreasing transitory SUI rate. Additional prospective and comparative studies on larger cohorts are needed to support these results.

\section{Declarations}

All methods were carried out in accordance with relevant guidelines and regulations

\section{Ethics approval and consent to participate:}

All Subjects have given their written informed consent

This study was approved by the ethics committee of the Hospices Civils de Lyon and registered with the CNIL (Commission Nationale de l'Informatique et des Libertés) under number 18-127.

\section{Consent for publication:}

NA

\section{Availability of data and materials:}


The datasets used and/or analysed during the current study available from the corresponding author on reasonable request.

\section{Competing interests:}

The authors have no competing interests to declare.

\section{Fundings:}

The authors received no specific funding for this work.

\section{Author Contributions:}

Fassi-Fehri Hakim and Codas Ricardo designed the study and supervised the project. YE Haixia collected and analysed the data. Fassi-Fehri Hakim and Codas Ricardo performed the operations. Badet Lionel, Daily Theresa and Colombel Marc aided in interpreting the results and worked on the manuscript. YE Haixia, FassiFehri Hakim and Codas Ricardo wrote the paper. All authors discussed the results and commented on the manuscript.

\section{Acknowledgements:}

none

\section{References}

1. Reich O, Gratzke C, Bachmann A, Seitz M, Schlenker B, Hermanek P, et al. Morbidity, Mortality and Early Outcome of Transurethral Resection of the Prostate: A Prospective Multicenter Evaluation of 10,654 Patients. J Urol. juill 2008;180(1):246-9.

2. Serretta V, Morgia G, Fondacaro L, Curto G, Lo bianco A, Pirritano D, et al. Open prostatectomy for benign prostatic enlargement in southern Europe in the late 1990s: a contemporary series of 1800 interventions. Urology. oct 2002;60(4):623-7.

3. Elzayat EA, Habib El, Elhilali MM. Holmium laser enucleation of the prostate: a size-independent new " gold standard ». Urology. nov 2005;66(5 Suppl):108-13.

4. Cornu J-N, Ahyai S, Bachmann A, de la Rosette J, Gilling P, Gratzke C, et al. A Systematic Review and Meta-analysis of Functional Outcomes and Complications Following Transurethral Procedures for Lower Urinary Tract Symptoms Resulting from Benign Prostatic Obstruction: An Update. Eur Urol. juin 2015;67(6):1066-96.

5. Cho MC, Park JH, Jeong MS, Yi J-S, Ku JH, Oh S-J, et al. Predictor of de novo urinary incontinence following holmium laser enucleation of the prostate. Neurourol Urodyn. sept 2011;30(7):1343-9.

6. Montorsi F, Naspro R, Salonia A, Suardi N, Briganti A, Zanoni M, et al. Holmium laser enucleation versus transurethral resection of the prostate: results from a 2-center, prospective, randomized trial in patients with obstructive benign prostatic hyperplasia. J Urol. nov 2004;172(5 Pt 1):1926-9. 
7. Nam JK, Kim HW, Lee DH, Han J-Y, Lee JZ, Park S-W. Risk Factors for Transient Urinary Incontinence after Holmium Laser Enucleation of the Prostate. World J Mens Health. août 2015;33(2):88-94.

8. Theodorou C, Moutzouris G, Floratos D, Plastiras D, Katsifotis C, Mertziotis N. Incontinence after surgery for benign prostatic hypertrophy: the case for complex approach and treatment. Eur Urol. 1998;33(4):370-5.

9. Shah HN, Mahajan AP, Hegde SS, Bansal MB. Peri-operative complications of holmium laser enucleation of the prostate: experience in the first 280 patients, and a review of literature. BJU Int. juill 2007;100(1):94-101.

10. Shigemura K, Tanaka K, Yamamichi F, Chiba K, Fujisawa M. Comparison of Predictive Factors for Postoperative Incontinence of Holmium Laser Enucleation of the Prostate by the Surgeons' Experience During Learning Curve. Int Neurourol J. mars 2016;20(1):59-68.

11. Lerner LB, Tyson MD, Mendoza PJ. Stress incontinence during the learning curve of holmium laser enucleation of the prostate. J Endourol. oct 2010;24(10):1655-8.

12. Minagawa S, Okada S, Morikawa H. Safety and Effectiveness of Holmium Laser Enucleation of the Prostate Using a Low-power Laser. Urology. déc 2017;110:51-5.

13. Placer J, Gelabert-Mas A, Vallmanya F, Manresa JM, Menéndez V, Cortadellas R, et al. Holmium laser enucleation of prostate: outcome and complications of self-taught learning curve. Urology. mai 2009;73(5):1042-8.

14. Gilling PJ, Cass CB, Cresswell MD, Fraundorfer MR. Holmium laser resection of the prostate: preliminary results of a new method for the treatment of benign prostatic hyperplasia. Urology. janv 1996;47(1):48-51.

15. Helfand BT, Smith AR, Lai HH, Yang CC, Gore JL, Erickson BA, et al. Prevalence and Characteristics of Urinary Incontinence in a Treatment Seeking Male Prospective Cohort: Results from the LURN Study. J Urol. août 2018;200(2):397-404.

16. Twiss CO, Fischer MC, Nitti VW. Comparison between reduction in 24-hour pad weight, International Consultation on Incontinence-Short Form (ICIQ-SF) score, International Prostate Symptom Score (IPSS), and Post-Operative Patient Global Impression of Improvement (PGI-I) score in patient evaluation after male perineal sling. Neurourol Urodyn. janv 2007;26(1):8-13.

17. Houssin V, Olivier J, Brenier M, Pierache A, Laniado M, Mouton M, et al. Predictive factors of urinary incontinence after holmium laser enucleation of the prostate: a multicentric evaluation. World $\mathrm{J}$ Urol [Internet]. 26 mars 2020 [cité 2 sept 2020]; Disponible sur: http://link.springer.com/10.1007/s00345-02003169-0

18. Lai HH, Helmuth ME, Smith AR, Wiseman JB, Gillespie BW, Kirkali Z. Relationship Between Central Obesity, General Obesity, Overactive Bladder Syndrome and Urinary Incontinence Among Male and Female Patients Seeking Care for Their Lower Urinary Tract Symptoms. Urology. janv 2019;123:34-43.

19. Elmansy HM, Kotb A, Elhilali MM. Holmium Laser Enucleation of the Prostate: Long-Term Durability of Clinical Outcomes and Complication Rates During 10 Years of Followup. J Urol. nov 2011;186(5):1972-6.

20. Kobayashi S, Yano M, Nakayama T, Kitahara S. Predictive risk factors of postoperative urinary incontinence following holmium laser enucleation of the prostate during the initial learning period. Int 
Braz J Urol Off J Braz Soc Urol. août 2016;42(4):740-6.

21. Krambeck AE, Handa SE, Lingeman JE. Experience With More Than 1,000 Holmium Laser Prostate Enucleations for Benign Prostatic Hyperplasia. J Urol [Internet]. janv 2013 [cité 9 janv 2020];189(1S). Disponible sur: http://www.jurology.com/doi/10.1016/j.juro.2012.11.027

22. Scoffone CM, Cracco CM. The en-bloc no-touch holmium laser enucleation of the prostate (HoLEP) technique. World J Urol. août 2016;34(8):1175-81.

23. Gomez Sancha F, Rivera VC, Georgiev G, Botsevski A, Kotsev J, Herrmann T. Common trend: move to enucleation-Is there a case for GreenLight enucleation? Development and description of the technique. World J Urol. 2015;33(4):539-47.

24. Endo F, Shiga Y, Minagawa S, Iwabuchi T, Fujisaki A, Yashi M, et al. Anteroposterior dissection HoLEP: a modification to prevent transient stress urinary incontinence. Urology. déc 2010;76(6):1451-5.

25. Elmansy H, Hodhod A, Kotb A, Prowse O, Shahrour W. Top-down Holmium Laser Enucleation of the Prostate: Technical Aspects and Early Outcomes. Urology. avr 2019;126:236.

26. Kampantais S, Dimopoulos P, Tasleem A, Acher P, Gordon K, Young A. Assessing the Learning Curve of Holmium Laser Enucleation of Prostate (HoLEP). A Systematic Review. Urology. oct 2018;120:9-22.

27. Shigemura K, Yamamichi F, Kitagawa K, Yamashita M, Oka Y, Tanaka H, et al. Does Surgeon Experience Affect Operative Time, Adverse Events and Continence Outcomes in Holmium Laser Enucleation of the Prostate? A Review of More Than 1,000 Cases. J Urol. sept 2017;198(3):663-70.

28. Aho T, Herrmann TRW. Description of a modular mentorship programme for holmium laser enucleation of the prostate. World J Urol. avr 2015;33(4):497-502.

\section{Tables}

Table 1: Patient's characteristics and urinary function 


\begin{tabular}{|c|c|}
\hline & Mean \pm Standard deviation or $\mathrm{N}$ \\
\hline \multicolumn{2}{|l|}{ Preoperative data } \\
\hline Age (year) & $69,53 \pm 7,58$ \\
\hline $\mathrm{BMI}\left(\mathrm{kg} / \mathrm{m}^{2}\right)$ & $26,25 \pm 4,13$ \\
\hline Diabetes & 34 \\
\hline Prostate cancer under active surveillance & 11 \\
\hline Prostate volume (mL) & $88,81 \pm 43,55$ \\
\hline $\mathrm{PSA}(\mathrm{ng} / \mathrm{mL})$ & $6,84 \pm 5,98$ \\
\hline ASA score (American Society of Anaesthesiology) (mean) & $2,04 \pm 0,71$ \\
\hline \multicolumn{2}{|l|}{ ASA Score } \\
\hline 1 & 36 \\
\hline 2 & 77 \\
\hline 3 & 42 \\
\hline Antiplatelet Agent & 31 \\
\hline Direct Oral Anticoagulant & 11 \\
\hline Antivitamin $\mathrm{K}$ & 5 \\
\hline Urinary catheterisation & 58 \\
\hline \multicolumn{2}{|l|}{ Operative data } \\
\hline General anaesthesia & 67 \\
\hline Spinal anaesthesia & 88 \\
\hline Length of surgery (min) & $105,68 \pm 48,93$ \\
\hline Volume of irrigation fluid (L) & $34,55 \pm 16,17$ \\
\hline Energy delivered $(\mathrm{kJ})$ & $201 \pm 99,59$ \\
\hline Enucleated weight (g) & $51,87 \pm 32,11$ \\
\hline Efficiency coefficient (weight enucleated/operating time) (g/min) & $0.49 \pm 0,20$ \\
\hline \multicolumn{2}{|l|}{ Postoperative data } \\
\hline Duration of irrigation (day) & $1,08 \pm 2,22$ \\
\hline Duration of urinary catheterisation (day) & $1,63 \pm 2,62$ \\
\hline Length of stay (day) & $1,86 \pm 2,43$ \\
\hline Hemoglobin loss (g/dL) & $1,29 \pm 1,24$ \\
\hline
\end{tabular}


Table 2: Urinary function follow-up and incidence of SUI

\begin{tabular}{|c|c|c|c|c|c|}
\hline & Baseline & 1 month & 3 months & 6 months & 12 months \\
\hline & \multicolumn{5}{|c|}{ Mean \pm Standard deviation or $\mathrm{N}(\%)$} \\
\hline Patients & 155 & 150 & 149 & 146 & 150 \\
\hline IPSS & $20.16 \pm 5.93$ & $7.49 \pm 4.73^{*}$ & $5.70 \pm 5.25^{\star}$ & $3.84 \pm 4.31^{\star}$ & $3.30 \pm 3.75^{\star}$ \\
\hline QOL & $4.59 \pm 1.34$ & $1.75 \pm 1.69 *$ & $1.28 \pm 1.48^{\star}$ & $0.82 \pm 0.97^{\star}$ & $0.69 \pm 0.84^{*}$ \\
\hline $\begin{array}{l}\text { Mean ICIO-SF } \\
\text { score (global) }\end{array}$ & $4.11 \pm 4.56$ & $3.69 \pm 5.20$ & $2.58 \pm 4.62$ & $1.81 \pm 3.53$ & $1.02 \pm 2.58$ \\
\hline Mean ICIQ-SF (SUI) & 0 & $11.69 \pm 5.28^{\star}$ & $8.70 \pm 4.24^{*}$ & $7.45 \pm 2.84^{*}$ & $8 \pm 4.24 *$ \\
\hline $\mathrm{Qmax}(\mathrm{mL} / \mathrm{s})$ & $8.56 \pm 3.85$ & $18.90 \pm 9.29 *$ & $22.90 \pm 11.06^{*}$ & $22.81 \pm 9.89 *$ & $23.43 \pm 11.66^{*}$ \\
\hline PVR (mL) & $165.07 \pm 147.23$ & $62.26 \pm 83.97 *$ & $60.31 \pm 60.63^{*}$ & $58.57 \pm 72.04^{\star}$ & $47.33 \pm 65.57 *$ \\
\hline $\mathrm{PSA}(\mathrm{ng} / \mathrm{mL})$ & $6.84 \pm 5.98$ & & $1.65 \pm 1.62^{\star}$ & & $1.95 \pm 2.05^{\star}$ \\
\hline SUI & 0 & $11(7.3 \%)$ & $12(8.1 \%)$ & $5(3.4 \%)$ & $4(2.7 \%)$ \\
\hline Other UI & $37(23.9 \%)$ & $50(33.3 \%)$ & $30(20.1 \%)$ & $21(14.4 \%)$ & $14(9.3 \%)$ \\
\hline $\begin{array}{l}\text { Patients with daily } \\
\text { pads for SUI }\end{array}$ & 0 & $8(5.3 \%)$ & $4(2.7 \%)$ & $2(1.4 \%)$ & $2(1.3 \%)$ \\
\hline
\end{tabular}

* $p<0.05$ compared to baseline

Table 3 : Univariate and multivariate logistic regression analysis for predicting postoperative stress urinary incontinence 


\begin{tabular}{|c|c|c|c|c|c|c|c|c|}
\hline \multirow[t]{3}{*}{ characteristics } & \multicolumn{4}{|l|}{1 month } & \multicolumn{4}{|l|}{3 months } \\
\hline & \multicolumn{2}{|l|}{$\begin{array}{l}\text { Univariate } \\
\text { analysis }\end{array}$} & \multicolumn{2}{|l|}{$\begin{array}{l}\text { Multivariate } \\
\text { analysis }\end{array}$} & \multicolumn{2}{|c|}{ Univariate analysis } & \multicolumn{2}{|l|}{$\begin{array}{l}\text { Multivariate } \\
\text { analysis }\end{array}$} \\
\hline & \multicolumn{8}{|c|}{ Odds ratio $(95 \% \mathrm{Cl}) \mathrm{p}$ value } \\
\hline $\begin{array}{l}\text { age }(<70 \\
\text { vs } \geq 70) \text {, years }\end{array}$ & $\begin{array}{l}2,25(0,79- \\
6,42)\end{array}$ & 0,13 & $\begin{array}{l}1,68(0,51- \\
5,48)\end{array}$ & 0,39 & $\begin{array}{l}14,37(1,81- \\
114,3)\end{array}$ & 0,012 & $\begin{array}{l}16,23(1,96- \\
134,09)\end{array}$ & 0,01 \\
\hline $\begin{array}{l}\mathrm{BMI}(<30 \text { vs } \\
\geq 30)\end{array}$ & $\begin{array}{l}5,19(1,79- \\
15,07)\end{array}$ & 0,002 & $\begin{array}{l}4,69(1,51- \\
14,52)\end{array}$ & 0,007 & $\begin{array}{l}2,49(0,76- \\
8,16)\end{array}$ & 0,13 & $\begin{array}{l}2,98(0,83- \\
10,72)\end{array}$ & 0,09 \\
\hline diabetes & $\begin{array}{l}1,21(0,36- \\
4,00)\end{array}$ & 0,757 & & & $\begin{array}{l}1,70(0,55- \\
5,31)\end{array}$ & 0,358 & & \\
\hline $\begin{array}{l}\text { ASA (<3 vs } \\
\geq 3)\end{array}$ & $\begin{array}{l}3,15(0,76- \\
13,1)\end{array}$ & 0,11 & & & $\begin{array}{l}1,38(0,39- \\
4,85)\end{array}$ & 0,61 & & \\
\hline $\begin{array}{l}\text { Anti- } \\
\text { aggregation or } \\
\text { anticoagulant } \\
\text { treatment }\end{array}$ & $\begin{array}{l}1,75(0,62- \\
4,93)\end{array}$ & 0,29 & & & $\begin{array}{l}1,39(0,47- \\
4,10)\end{array}$ & 0,545 & & \\
\hline $\begin{array}{l}\text { Prostate } \\
\text { volume }(<90 \\
\text { vs } \geq 90), \mathrm{g}\end{array}$ & $\begin{array}{l}0,86(0,31- \\
2,39)\end{array}$ & 0,77 & & & $\begin{array}{l}0,6(0,17- \\
2,08)\end{array}$ & 0,42 & & \\
\hline $\begin{array}{l}\text { Urinary } \\
\text { catheterism }\end{array}$ & $\begin{array}{l}1,19(0,43- \\
3,33)\end{array}$ & 0,73 & & & $\begin{array}{l}0,82(0,24- \\
2,87)\end{array}$ & 0,76 & & \\
\hline $\begin{array}{l}\text { Enucleation } \\
\text { time ( } \geq 60 \text { vs } \\
<60) \text {, min }\end{array}$ & $\begin{array}{l}2,78(0,86- \\
8,98)\end{array}$ & 0,09 & & & $\begin{array}{l}0,97(0,2- \\
4,7)\end{array}$ & 0,97 & & \\
\hline $\begin{array}{l}\text { Operating } \\
\text { time }(\geq 90 \text { vs } \\
<90) \text {, min }\end{array}$ & $\begin{array}{l}0,67(0,24- \\
1,85)\end{array}$ & 0,44 & & & $\begin{array}{l}0,78(0,24- \\
2,52)\end{array}$ & 0,67 & & \\
\hline $\begin{array}{l}\text { Energy } \\
\text { delivered } \\
(<200 \text { vs } \\
\geq 200) \text {, kJ }\end{array}$ & $\begin{array}{l}1,31(0,48- \\
3,6)\end{array}$ & 0,6 & & & $\begin{array}{l}1,02(0,31- \\
3,38)\end{array}$ & 0,97 & & \\
\hline $\begin{array}{l}\text { Enucleated } \\
\text { weight (<50 vs } \\
\geq 50), \mathrm{g}\end{array}$ & $\begin{array}{l}1,38(0,5- \\
3,79)\end{array}$ & 0,53 & & & $\begin{array}{l}1,2(0,37- \\
3,9)\end{array}$ & 0,76 & & \\
\hline $\begin{array}{l}\text { Efficiency } \\
\text { coefficient } \\
(<0.5 \mathrm{vs} \\
\geq 0.50), \mathrm{g} / \mathrm{min}\end{array}$ & $\begin{array}{l}1,38(0.50- \\
3.80)\end{array}$ & 0,529 & & & $\begin{array}{l}1,20(0,37- \\
3,91)\end{array}$ & 0,759 & & \\
\hline \multirow[t]{2}{*}{ characteristics } & \multicolumn{4}{|l|}{6 months } & \multicolumn{4}{|l|}{12 months } \\
\hline & $\begin{array}{l}\text { Univariate } \\
\text { analysis }\end{array}$ & & $\begin{array}{l}\text { Multivariate } \\
\text { analysis }\end{array}$ & & Univariate ar & alysis & $\begin{array}{l}\text { Multivariate } \\
\text { analysis }\end{array}$ & \\
\hline
\end{tabular}




\begin{tabular}{|c|c|c|c|c|c|c|c|c|}
\hline $\begin{array}{l}\text { age }(<70 \\
\text { vs } \geq 70) \text {, years }\end{array}$ & $\begin{array}{l}5,96(0,68- \\
52,22)\end{array}$ & 0,11 & $\begin{array}{l}6,27(0,67- \\
59,03)\end{array}$ & 0,11 & $\begin{array}{l}4,7(0,51- \\
43,01)\end{array}$ & 0,17 & $\begin{array}{l}5,04(0,47- \\
53,84)\end{array}$ & 0,18 \\
\hline $\begin{array}{l}\text { BMI }(<30 \text { vs } \\
\geq 30)\end{array}$ & $\begin{array}{l}2,39(0,46- \\
12,28)\end{array}$ & 0,3 & $\begin{array}{l}2,45(0,42- \\
14,23)\end{array}$ & 0,32 & $\begin{array}{l}3,16(0.32- \\
30.75)\end{array}$ & 0,322 & $\begin{array}{l}1,17(0,09- \\
15,64)\end{array}$ & 0.906 \\
\hline diabetes & $\begin{array}{l}0,70(0,08- \\
6,24)\end{array}$ & 0,752 & & & $\begin{array}{l}0,88(0,10- \\
8,18)\end{array}$ & 0,913 & & \\
\hline $\begin{array}{l}\text { ASA }(<3 \text { vs } \\
\geq 3)\end{array}$ & $\begin{array}{l}1,36(0,24- \\
7,73)\end{array}$ & 0,73 & & & $\begin{array}{l}1,83(0,3- \\
11,38)\end{array}$ & 0,52 & & \\
\hline $\begin{array}{l}\text { Anti- } \\
\text { aggregation or } \\
\text { anticoagulant } \\
\text { treatment }\end{array}$ & $\begin{array}{l}0,45(0,05- \\
3,98)\end{array}$ & 0,474 & & & $\begin{array}{l}0,54(0,06- \\
4,95)\end{array}$ & 0,584 & & \\
\hline $\begin{array}{l}\text { Prostate } \\
\text { volume }(<90 \\
\text { vs } \geq 90) \text {, g }\end{array}$ & $\begin{array}{l}1,26(0,25- \\
6,44)\end{array}$ & 0,78 & & & $\begin{array}{l}0,83(0,13- \\
5,09)\end{array}$ & 0,84 & & \\
\hline $\begin{array}{l}\text { Urinary } \\
\text { catheterism }\end{array}$ & $\begin{array}{l}0,32(0,04- \\
2,83)\end{array}$ & 0,31 & & & $\begin{array}{l}0,43(0,05- \\
3,98)\end{array}$ & 0,461 & & \\
\hline $\begin{array}{l}\text { Enucleation } \\
\text { time }(\geq 60 \text { vs } \\
<60) \text {, min }\end{array}$ & $\begin{array}{l}0,97(0,11- \\
8,65)\end{array}$ & 0,98 & & & $\begin{array}{l}1,22(0,13- \\
11,39)\end{array}$ & 0,86 & & \\
\hline $\begin{array}{l}\text { Operating } \\
\text { time }(\geq 90 \text { vs } \\
<90) \text {, min }\end{array}$ & $\begin{array}{l}0,78(0,15- \\
4,01)\end{array}$ & 0,77 & & & $\begin{array}{l}0,52(0,08- \\
3,18)\end{array}$ & 0,48 & & \\
\hline $\begin{array}{l}\text { Energy } \\
\text { delivered } \\
(<200 \text { vs } \\
\geq 200) \text {, kJ }\end{array}$ & $\begin{array}{l}0,7(0,13- \\
3,97)\end{array}$ & 0,69 & & & $\begin{array}{l}0,95(0,15- \\
5,86)\end{array}$ & 0,96 & & \\
\hline $\begin{array}{l}\text { Enucleated } \\
\text { weight }(<50 \text { vs } \\
\geq 50), \mathrm{g}\end{array}$ & $\begin{array}{l}6,29(0,72- \\
55,14)\end{array}$ & 0,1 & & & $\begin{array}{l}1,81(0,29- \\
11,14)\end{array}$ & 0,52 & & \\
\hline $\begin{array}{l}\text { Efficiency } \\
\text { coefficient } \\
(<0.5 \mathrm{vs} \\
\geq 0.50), \mathrm{g} / \mathrm{min}\end{array}$ & $\begin{array}{l}6,31(0,72- \\
55,33)\end{array}$ & 0,096 & & & $\begin{array}{l}4,97(0,54- \\
45,54)\end{array}$ & 0,156 & & \\
\hline
\end{tabular}

Table 4: Stress urinary stress incontinence rates after HoLEP reported in the literature 


\begin{tabular}{|c|c|c|c|c|c|c|}
\hline $\begin{array}{l}\text { Authors } \\
\text { Years }\end{array}$ & Patients & $\begin{array}{l}\text { Surgical } \\
\text { technique } \\
\text { and setting }\end{array}$ & $\begin{array}{l}\text { Centres } \\
\text { Operators }\end{array}$ & $\begin{array}{l}\text { Continence } \\
\text { questionnaires }\end{array}$ & $\begin{array}{l}\text { SUl before } 1 \\
\text { year }\end{array}$ & $\begin{array}{l}\text { SUl at } 1 \\
\text { year }\end{array}$ \\
\hline \multirow{2}{*}{$\begin{array}{l}\text { Placer, } 2009 \\
\text { (13) }\end{array}$} & \multirow[t]{2}{*}{125} & 3 lobes & Monocentric & \multirow[t]{2}{*}{ Yes, ICIQ-SF } & $6(4,8 \%)$ & \multirow[t]{2}{*}{$6(4,8 \%)$} \\
\hline & & 2J-50 Hz & 1 surgeon & & At 6 months & \\
\hline \multirow{2}{*}{$\begin{array}{l}\text { Shuichiro } \\
\text { Kobayashi, } \\
2016 \\
(20)\end{array}$} & \multirow[t]{2}{*}{127} & 3 lobes & Monocentric & \multirow[t]{2}{*}{ No } & $17(13,3 \%)$ & $2(1,5 \%)$ \\
\hline & & $100 \mathrm{~W}$ & 2 surgeons & & At 3 months & $\begin{array}{l}\text { (mixed } \\
\mathrm{UI})\end{array}$ \\
\hline \multirow{2}{*}{$\begin{array}{l}\text { Jong Kil Nam, } \\
2015 \text { (7) }\end{array}$} & \multirow[t]{2}{*}{391} & 3 lobes & Monocentric & \multirow[t]{2}{*}{ No } & $13(3,3 \%)$ & \multirow[t]{2}{*}{$1(0,3 \%)$} \\
\hline & & $2 \mathrm{j}, 40 \mathrm{~Hz}$ & 1 surgeon & & At 3 months & \\
\hline \multirow{2}{*}{$\begin{array}{l}\text { Jeongyun } \\
\text { Jeong, } \\
2015 \text { (29) }\end{array}$} & \multirow[t]{2}{*}{110} & 3 lobes & Monocentric & \multirow[t]{2}{*}{ Yes, ICIQ-SF } & - & \multirow[t]{2}{*}{-} \\
\hline & & $\begin{array}{l}80-100 \\
W\end{array}$ & 1 surgeon & & & \\
\hline \multirow{2}{*}{$\begin{array}{l}\text { Elzayat, } 2005 \\
\text { (3) }\end{array}$} & \multirow[t]{2}{*}{552} & 3 lobes & Monocentric & \multirow[t]{2}{*}{ No } & $24(4,2 \%)$ & \multirow[t]{2}{*}{$3(0,5 \%)$} \\
\hline & & $80-100 \mathrm{~W}$ & 1 surgeon & & $\begin{array}{l}\text { Between } 1 \\
\text { and } 6 \\
\text { months }\end{array}$ & \\
\hline \multirow{2}{*}{$\begin{array}{l}\text { Shah, } 2007 \\
(9)\end{array}$} & \multirow[t]{2}{*}{280} & $2-3$ lobes & Monocentric & \multirow[t]{2}{*}{ No } & - & \multirow[t]{2}{*}{$2(0,7 \%)$} \\
\hline & & 2J $50 \mathrm{~Hz}$ & 1 surgeon & & & \\
\hline \multirow{2}{*}{$\begin{array}{l}\text { Vavassori, } 2008 \\
\text { (30) }\end{array}$} & \multirow[t]{2}{*}{330} & 3 lobes & Monocentric & \multirow[t]{2}{*}{ No } & $24(7,3 \%)$ & \multirow[t]{2}{*}{$2(0,6 \%)$} \\
\hline & & $\begin{array}{l}60-80- \\
100 W\end{array}$ & 1 surgeon & & At 3 months & \\
\hline \multirow{2}{*}{$\begin{array}{l}\text { Elmansy, } 2011 \\
\text { (19) }\end{array}$} & \multirow[t]{2}{*}{949} & - & Monocentric & \multirow[t]{2}{*}{ No } & $47(4,9 \%)$ & \multirow[t]{2}{*}{$8(1,04 \%)$} \\
\hline & & & 1 surgeon & & At 3 months & \\
\hline Krambeck, & \multirow[t]{2}{*}{1065} & 3 lobes & Moncentric & \multirow[t]{2}{*}{ No } & $60(12,5 \%)$ & $5(1,8 \%)$ \\
\hline $2013(21)$ & & & $\begin{array}{l}\text { Several } \\
\text { surgeons }\end{array}$ & & At 3 months & \\
\hline Lerner, 2010 & 77 & 3 lobes & Monocentric & No & $17(26 \%)$ & $2(3 \%)$ \\
\hline (11) & & & 1 surgeon & & At 3 months & \\
\hline Cho, 2011(5) & 204 & 3 lobes & Bicentric & No & $9(5 \%)$ & $2(1,1 \%)$ \\
\hline & & 2,6J, $30 \mathrm{~Hz}$ & $\begin{array}{l}\text { Several } \\
\text { surgeons }\end{array}$ & & At 3 months & \\
\hline Minagawa, & 74 & En-Bloc & Monocentric & Yes & $3(5,5 \%)$ & - \\
\hline 2017 (12) & & 1.5J, $20 \mathrm{~Hz}$ & 3 surgeons & ICIQ-SF & At 3 months & \\
\hline
\end{tabular}




\begin{tabular}{|lclllll|}
$\begin{array}{l}\text { Elmansy, } 2019 \\
(25)\end{array}$ & 60 & Top-down & $\begin{array}{l}\text { Monocentric } \\
\text { 1 surgeon }\end{array}$ & No & $2(3,3)$ & - \\
\hline Our Study & 155 & $\begin{array}{l}3 \text { lobes }+ \\
\text { white line }\end{array}$ & Monocentric & Yes & $12(10,7 \%)$ & $4(2,6 \%)$ \\
& & 2 J, so Hz & surgeons & ICIQ-SF & At 3 months & \\
& & & & & \\
\hline
\end{tabular}

\section{Figures}

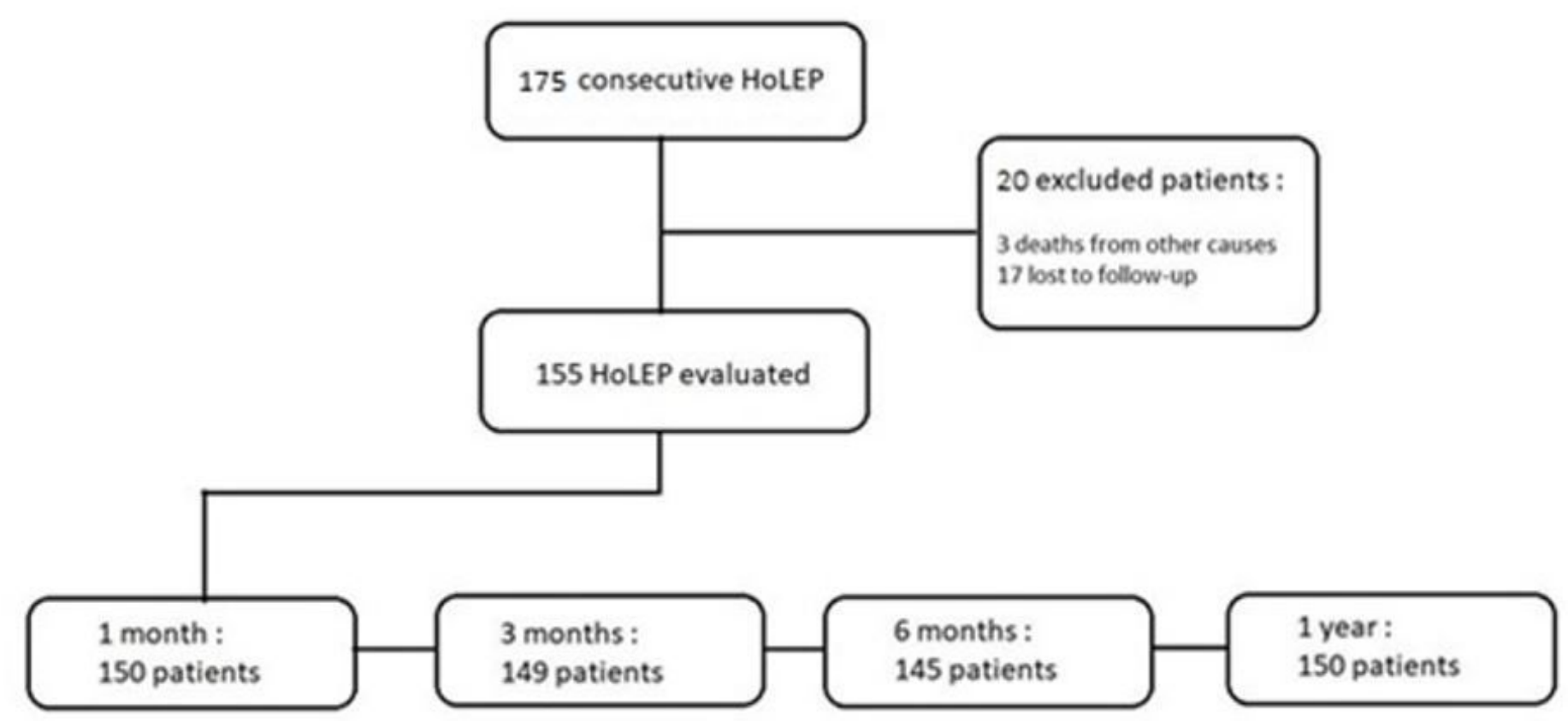

Figure 1

Flow chart 